\title{
Environmental and social effects of the change of heat sources on the example of a selected quarter of tenement houses in Wroclaw
}

\author{
Małgorzata Szulgowska-Zgrzywa ${ }^{1, *}$, Magdalena Baborska-Narożny ${ }^{2}$, \\ Krzysztof Piechurski ${ }^{1}$, Ewelina Stefanowicz ${ }^{1}$, Agnieszka Chmielewska $^{1}$, \\ Natalia Fidorów-Kaprawy ${ }^{1}$, and Marta Laska $^{1}$ \\ ${ }^{1}$ Wroclaw University of Science and Technology, Faculty of Environmental Engineering, \\ Wybrzeże Wyspiańskiego 27, 50-370 Wroclaw, Poland \\ ${ }^{2}$ Wroclaw University of Science and Technology, Faculty of Architecture, Wybrzeże \\ Wyspiańskiego 27, 50-370 Wroclaw, Poland
}

\begin{abstract}
The energy consumption for space heating and domestic hot water preparation are significant burdens of a polish household budget, especially in old tenement houses. Simultaneously, lowering the emission of pollutants is under the great importance and one of main goals to achieve in big cities. This policy results in the need of elimination of systems based on solid fuels. The article analyses the environmental and social consequences of the exchange of heat sources in such buildings in one of the quarters in Wroclaw. It presents how this change will affect the levels of low emission and costs of energy supply to tenement buildings.
\end{abstract}

\section{Introduction}

The significant components of the world energy balance in a group of residential buildings are the energy consumed on heating, domestic hot water preparation and additional electrical energy for other purposes in residential buildings. The strict requirements regarding building insulation in newly constructed buildings [1] open possibilities to utilize energy sources based on renewables. Implementation of such solutions can be twofold, due to financial and environmental impact. These two aspects can be met also by utilizing high-efficiency, modern conventional heating systems, where the low pollution level is achieved and the operating costs are acceptable to users. However, when the residential buildings built before the Second World War are under consideration, the solutions suitable for new buildings in many cases cannot be applied. In Poland, one can find a huge stock of such buildings that are often in very bad condition, while the process of the pre-war urban areas revitalisation had not yet reached the satisfactory level. It needs to be emphasised that the revitalisation of those buildings is a difficult and complex process [2]. A modernisation of such objects should ensure that they meet the requirements of the Technical Regulations

\footnotetext{
*Corresponding author: malgorzata.szulgowska-zgrzywa@pwr.edu.pl
} 
[1] when at the same time, in the field of thermal protection, such changes are limited by regulations regarding conservatory protection. As a result, a typical range of thermomodernization concerns the replacement of heat sources and modernization of the heating installation, not always including insulating the building's envelope and thus not lowering energy demands. Unfortunately, such approach generates a serious social problem - high heating costs that contribute to the increase of energy poverty. This problem is particularly visible in Poland, where old buildings are often inhabited by the poorest part of the society. Therefore, it is necessary to develop a fair policy concerning this problem and to include it in planning of a revitalization of pre-war urban areas. The publications [3-6] and the new directive on nearly-zero energy buildings [7] pay attention to this problem. The aim of the thermomodernization of historic buildings should be not only to reduce $\mathrm{CO}_{2}$ emission but also to respect social rights, which are a feature of sustainable development. Following the report of IBS (The Institute for Structural Research) [3] "energy poverty is still considered a marginal issue in Poland". The EU agrees that an energy poverty problem is spread across Europe, as between 50 and 125 million people [4] are unable to afford proper indoor thermal comfort. Ten years ago only 4 European countries (France, Ireland, Slovakia and UK) had an official definition of energy poverty [4]. Nowadays this issue is much wider discussed, however a definition of the poverty is still differently interpreted depending on the country.

Following the author [3] the energy poverty can be measured twofold: by the subjective assessment of the respondent group or the objective, based mostly on the data related to income and expenditure. The structure of expenditure in polish household budget is presented in special governmental reports prepared on regular basis, every few years, by Statistics Poland [5]. According to this document, the cost of energy carriers consumes on average $12 \%$ of household budget. A feedback from subjective assessment states that almost $91 \%$ of respondents in Poland in 2017 assessed their homes in winter season as adequately warm [5]. In this group are people with the lowest income ( $86 \%$ of this group) and with the highest (94\% of the richest group). The level of available income is calculated in the relation to the average monthly available income per person for total households in Poland (defined as $100 \%$ ). The group with highest available income reaches $193.1 \%$ of average for Polish households, the lowest is 59\% lower that the Polish average [5]. About 14\% from the lowest income group have problems with the mould, dampness or leaking roof at their homes and, at the same time, this problem touches only 3.5\% from the richest group. The same report [5] states that among poorest group of households only $76.6 \%$ are equipped in central heating and $92 \%$ in hot running water, in comparison to the total households in Poland - urban and rural areas, while in the richest group it is $92.1 \%$ and $99,5 \%$ respectively. These are still significant differences, but following the authors of the report, it improves form year to year. In 2017, the average monthly outgoings for housing, water, electricity, gas and other fuels calculated for all socio-economic group reached about 231 PLN per capita [5].

Earlier report [6] states that $12.2 \%$ (4.6 million) of Polish inhabitants in 2016 suffered from the energy poverty. What was underlined, and what is very interesting, 2.1 million of them did not suffer from financial poverty. This issue and change in energy poverty within groups suffering/not suffering economic poverty between 2012 and 2016 is clearly presented in the publication [6] and proves the former findings described in [5]. It means, the energy poverty should be analysed as a "separate dimension of deprivation" [6]. The authors of this research also noticed the relationship: the older the building, the poorer residents in terms of energy. It was found that the residents of tenement houses, built before 1946, cover almost $40 \%$ of all residents of multi-family premises suffering energy poverty. The research led to the conclusion, that energy poverty rate in tenements is twice as high as among families living in buildings constructed after 1946.

This article analyses the environmental and social consequences of the exchange of heat sources in tenement houses in one of the quarters of Wroclaw development. The aim of the 
study is to show how this exchange will affect the emission of pollutants but also to show its social effects, i.e. how it will change the costs of energy supply to these buildings.

\section{Description of the investigated quarter}

There are 30 residential facilities located in the examined quarter. Their location is shown in Fig.. The age structure of the tenement houses is not diverse, most of them come from 1880 1912. The exception are two buildings from the 90s' of the twentieth century. Among the buildings of examined quarters only two underwent renovation. The detailed age structure of the quarter, including renovations, is presented in Fig. 2.

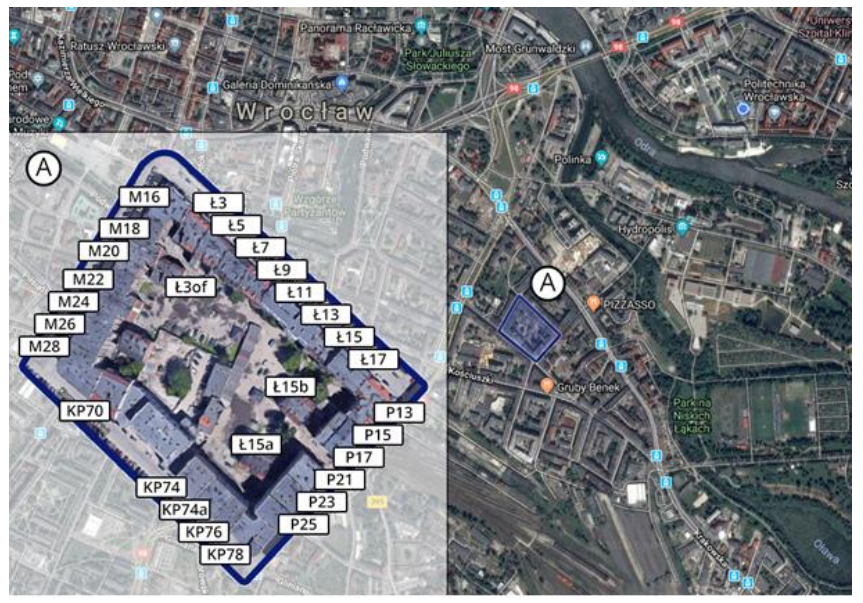

Fig. 1. The investigated quarter and key areas of Wroclaw.

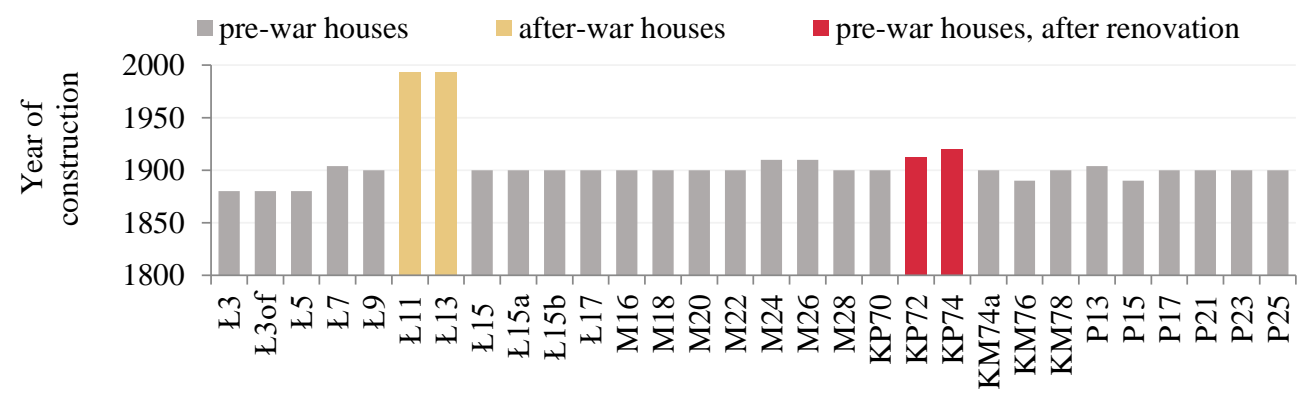

Fig. 2. Years of building construction.

The total usable floor area of the facilities is $26985 \mathrm{~m}^{2}$; of which $24635 \mathrm{~m}^{2}$ is the usable area of flats and $1585 \mathrm{~m}^{2}$ is the area of service premises or another heated one. About $6 \%$ of apartments are vacant, equivalent to $1471 \mathrm{~m}^{2}$. Most of the tenement houses analysed are objects from 500 to $1000 \mathrm{~m}^{2}$ of floor area. Only four tenements have a floor area slightly larger than $1000 \mathrm{~m}^{2}$, and only KM72 has an area exceeding $2500 \mathrm{~m}^{2}$. The structure of the surface of buildings is presented in (divided into apartments, vacant and other). The total number of apartments in tenement houses is 480, of which 300 are communal and 180 ownership flats. 


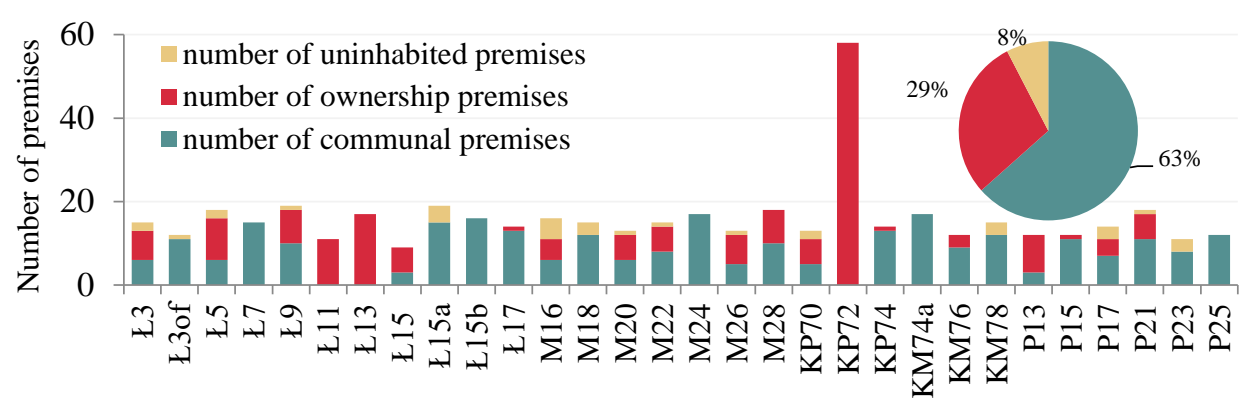

Fig. 3. The number of ownership and communal premises in individual facilities and uninhabited premises.

\section{Summary of results}

Information on heat sources in buildings were obtained from administrators of individual tenement houses or flats. However, administrators showed various involvement and willingness to provide information. Additionally, due to the significant age of the majority of the analyzed buildings, there is often lack of detailed construction documentation. Some documents were lost during the flood in Wroclaw in 1997. Nevertheless, the collected data made it possible to describe a significant number of flats considered in the study. Data from administrators were compared with survey results (as described in detail in the report [2]). It was found that both, in relation to the number of residential premises and their usable area, data on the types of heat sources used in buildings were very similar. This led to the conclusion that the information held by property managers in most cases were up to date and could be the background for the further analysis.

The Fig. 4 contains information about the heating systems related to flats floor area. The data comes from 424 residential premises from total of 480 covered by the study (i.e. $88 \%$ of the samples were described).

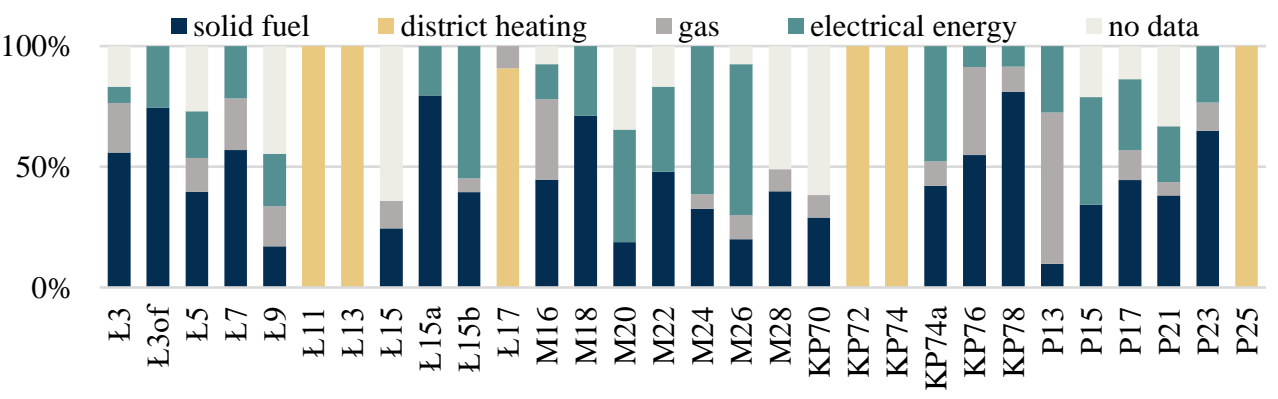

Fig. 4. A share of particular types of heat sources in relation to the surface of residential premises.

In a similar way, systems for domestic hot water (DHW) preparation in individual tenement houses were described (Fig.). In buildings in which heat from a district heating network is used for heating purposes, preparation of DHW is also based on this form of heat. Other dwellings use systems based on natural gas or electricity, with the significant majority of the electrical systems. It should be noticed that while the data collected from administrators concerning heating systems used for space heating allowed to describe $88 \%$ of the sample, the amount of data obtained for domestic hot water preparation system covers 362 flats, which constitutes $75 \%$ of the surveyed sample. 


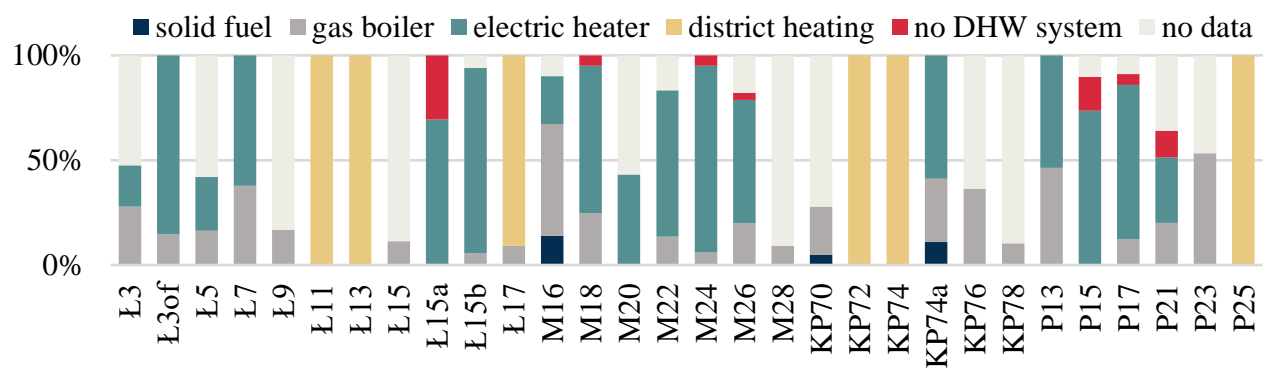

Fig. 5. Type of heat source to prepare domestic hot water in relation to the surface of residential premises.

The structure of heat sources for the analyzed city area is presented in Fig.. Data deficiencies were completed by extrapolating the results for flats powered by gas, coal and electricity. Apartments connected to district heating system were diagnosed at $100 \%$. In the examined quarter, it was found that $2.2 \%$ of dwellings still do not have a system for DHW preparation. However, it was assumed that these systems will ultimately be made.
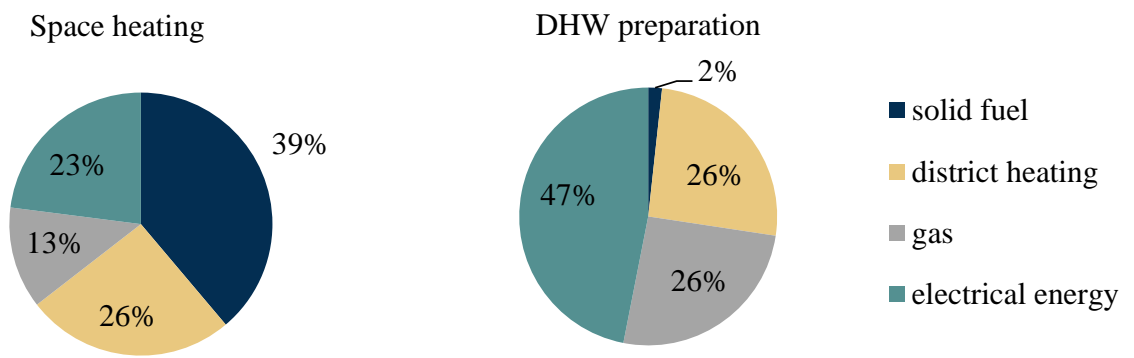

Fig. 6. Structure of heat sources for space heating and domestic hot water preparation for surveyed tenement houses.

\section{Operating costs and emission of pollutants in the examined quarter of tenements}

\subsection{Simulation data}

The analysis of energy consumption for the whole quarter and the discussion about the thermomodernization was based the data on the heat energy, electricity and water consumption obtained for three types of tenement houses:

- Type I - a tenement house from the turn of the $19^{\text {th }} / 20^{\text {th }}$ century after thermomodernization (according to background research, heated to about $20^{\circ} \mathrm{C}$ ),

- Type II - a tenement house from the turn of the $19^{\text {th }} / 20^{\text {th }}$ century without thermomodernization (according to background research, heated to about $20^{\circ} \mathrm{C}$ ),

- Type III - a tenement house from the turn of the $19^{\text {th }} / 20^{\text {th }}$ century without thermomodernization (according to background research, partly unheated).

The basis for the analysis of the energy demand was the actual heating energy consumption, which was calculated based on the real consumption of electricity and district heat in the previous year. That heating season was much warmer than the average calculated 
heating season in Poland, and thus the demand for energy in the statistical heating season can be higher even about $45 \%$. These data were provided by the facility managers and/or by the electricity supplier. The actual specific energy consumption for heating purposes variated depending on building type, namely:

- $\quad$ Type I: about $50 \mathrm{kWh} / \mathrm{m}^{2}$ per year

- Type II: average $150 \mathrm{kWh} / \mathrm{m}^{2}$ per year

- Type III: average $85 \mathrm{kWh} / \mathrm{m}^{2}$ per year

As it can be noticed, that tenement houses without thermomodernization (Type II) in the previous heating season are characterized by very high thermal energy demand, about $150 \mathrm{kWh} / \mathrm{m}^{2}$ per annum. Lower energy consumption in Type III facilities probably results from intentional actions of the owners, i.e. deliberate un-heating chosen rooms and/or problem with maintaining the internal temperature of $20^{\circ} \mathrm{C}$ in winter. In the buildings of Type I, low energy consumption probably effects from the thermomodernization that has been already carried out. The average DHW consumption in premises in the examined quarter was $500 \mathrm{l} / \mathrm{m}^{2}$ per annum and electrical energy consumption for other purposes than heating was $27.8 \mathrm{kWh} / \mathrm{m}^{2}$ per annum.

\subsection{The summary of the results of energy costs for the examined quarter}

The Fig. 7 presents the costs of heating and DHW preparation expressed in PLN $/ \mathrm{m}^{2}$ per year. They were calculated on a basis of energy consumption for the space heating of flats in II ${ }^{\text {nd }}$ type of tenement houses and the average hot water consumption for the exmained quarter.

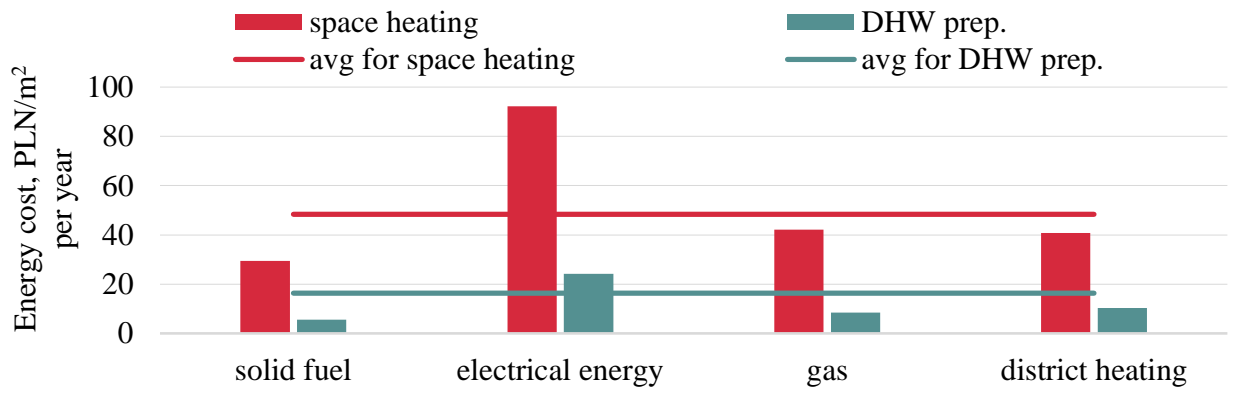

Fig. 7. Unit cost of heating and DHW preparation in II ${ }^{\text {nd }}$ type of tenement houses depending on the type of fuel, related to average energy costs for the examined quarter.

Differences are large. The average cost of space heating in the quarter is $49 \mathrm{PLN} / \mathrm{m}^{2}$ per annum. In flats supplied in heat from a district network and gas heating costs are relatively close to this value. Apartments heated by coal have lower running costs, which are usually the justification for inhabitants to use of this fuel in spite of generating low emissions. It is also worth to look at the problem of residents who have changed the heat source from coal to electricity. The reason for such a change was, on the one hand, the need to replace the old heat source and, on the other hand, usually the insufficient budget for installing a more expensive, in terms of investment costs, system based on natural gas. As a result, in order to keep space heating costs at an acceptable level, they do not heat their flats to comfort conditions (67\% of flats). It should also be noticed that in apartments heated with coal the problem of under-heating is also frequent (32\% of flats) [2]. It usually results from insufficient household budget. On a monthly basis, the cost of space heating based on solid fuel is $2.5 \mathrm{PLN} / \mathrm{m}^{2}$ per month. They should be considered as significant and strongly affecting the household budget. Heating based on gas and district heating generates costs of about 3.5 $\mathrm{PLN} / \mathrm{m}^{2}$ per month when electrical heating even up to $7.7 \mathrm{PLN} / \mathrm{m}^{2}$ per month. It should be 
emphasized once again that the analysed heating season is warmer than the average and thus the real costs may be higher. One should also remember that the considered costs are average for examined quarter and costs may be higher also due to the location of the apartment in the building (ground floor, last floor or corner of the building). The simulation of energy costs (for heating, DHW and supply in electrical energy) for a flat with a floor area of $55 \mathrm{~m}^{2}$ is presented below (Fig. 8). This is the average floor area of the flats in the analysed quarter. The analysis was performed for several configurations of heating systems, their designations are described below the figure. The value of the average energy cost for such a flat for the examined quarter is marked by a horizontal line (avg energy cost).

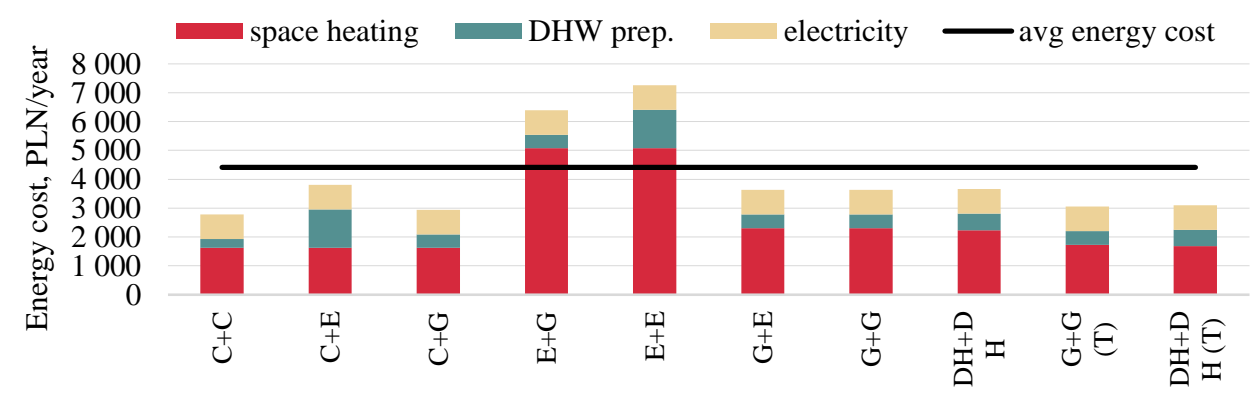

Fig. 8. Energy costs for a flat with a floor area of $55 \mathrm{~m}^{2}$, depending on the configuration of the heating system, related to the average energy costs for the examined quarter. The letters in $\mathrm{X}$ axis description states for: C-coal, E-electricity, G-gas, DH-district heating, T-building after thermomodernization. The first letter states for space heating, the second for DHW (ex. C+C: coal is used for space heating and DHW purposes).

The diversity between energy costs is huge. Flats that are mainly supplied with electricity and heated to $+20^{\circ} \mathrm{C}$, even in a relatively warm heating season, generate costs that are far too high. They constitute, assuming obtaining income on the level of two minimum salaries (currently PLN 1613 net), 16.5\% of the household budget for dwellings type E + G (Fig.8) and $18.8 \%$ for dwellings type $\mathrm{E}+\mathrm{E}$. The undertaken studies have shown that the highest percentage of insufficient heated flats $(67 \%)$ is in the group heated by electricity, which confirms that these costs are too high. Energy costs for apartments with a heating system based on coal are significantly lower and their share in the household budget with the aforementioned assumptions does not exceed 12\% (the average value for Poland [5]). A change from coal to gas heating system or district heating will result in an increase in energy expenditure by around $32 \%$. Almost certainly such a change would be the unbearable burden for the inhabitants of these flats. Therefore when the revitalization of areas such as the examined quarter is taken under consideration, two aspects need to be taken into account: replacement of heat sources based on solid fuels to the systems based on district heating or natural gas, but also subsidizing the replacement of electric heating, especially if the earlier replacement was dictated by financial constraints. It is very important to make an attempt to reduce the energy demand in the facility by about $25 \%$ (thermomodernization) simultaneously with the replacement of heat sources. The effects of such actions are shown in Fig. 8 as results marked $\mathrm{G}+\mathrm{G}(\mathrm{T})$ and $\mathrm{DH}+\mathrm{DH}(\mathrm{T})$. Energy costs in such variants remained at a similar level as with utilization of coal heating, namely the share of energy costs in the household budget is $8 \%$ (related to two minimum wages).

\subsection{Summary of low emission results for the quarter}

The change in the heating system results in a change in energy costs, but heating systems' changes are primarily due to the need to reduce low emissions in cities. As an example of the 
effects of the exchange of heat sources in the examined quarter, the estimated values for dusts, sulphur oxides, nitrogen oxides and carbon monoxide are presented (Tab.1). The reduction of low emissions for dust, $\mathrm{SOx}$ and $\mathrm{CO}$ is $99.9 \%$, and for oxides of nitrogen about $90 \%$.

Table 1. Emission of harmful substances (kg/annum).

\begin{tabular}{|c|c|c|c|c|}
\hline & $\mathrm{PM}$ & $\mathrm{SO}_{\mathrm{x}}$ & $\mathrm{NO}_{\mathrm{x}}$ & $\mathrm{CO}$ \\
\hline actual state & 57.72 & 76.98 & 1109.52 & 33673.59 \\
\hline abandonment of solid fuels & 0.04 & 0.06 & 108.93 & 21.50 \\
\hline abandonment of solid fuels and thermomodernization & 0.03 & 0.05 & 99.72 & 19.68 \\
\hline
\end{tabular}

\section{Conclusions}

The need to reduce low emissions in cities requires the elimination of solid fuel systems. These are still common in Polish cities, especially in the areas of old pre-war buildings. In the surveyed quarter, $39 \%$ of the area of heated dwellings is still supplied from coal as energy source. At the same time, it should be noted that the problem of energy poverty mainly affects the residents of such tenement houses [3-6]. Replacing the coal heat sources for heating based on natural gas or district heating without any additional technical improvements on building envelope will increase energy costs by around 32\%. It may exceed the possibilities of home residents' budgets. It is therefore necessary to carry out thermomodernization simultaneously and introduce appropriate subsidy programmes. Additionally in the process of exchanging heat sources, also inhabitants who had already exchanged coal heating for electricity should be taken into account. This exchange was often caused by the lack of funds for a better and more expensive (in initial costs) heating system and effects in significant under-heating and not maintaining minimal comfort conditions in these flats resulting from excessive energy costs. It seems that a careful diagnosis of this problem is needed in order to preserve social justice and protect residents of pre-war tenement houses from energy poverty.

\section{References}

1. Rozporządzenie Ministra Infrastruktury w sprawie warunków technicznych jakim powinny odpowiadać budynki i ich usytuowanie, Rozporządzenie z dnia 12 kwietnia 2002 r. (Dz.U. Nr 75, poz. 690 z późn. zm.)

2. M. Baborska-Narożny, M. Szulgowska-Zgrzywa, N. Fidorów-Kaprawy, A. Chmielewska, M. Laska, E. Stefanowicz, K. Piechurski, Ciepło w domu, gdy zimno na dworze (Technical report, 2018)

3. A. Szpor, Energy poverty in Poland - buzzword or a real problem? (IBS policy paper, 2016)

4. Tackling Fuel Poverty in Europe, Recommendations Guide for Policy Makers, Report produced in the framework of the Intelligent Energy Europe project EPEE-European Fuel Poverty and Energy Efficiency (2009)

5. Household budget survey in 2017, Statistical Information, GUS, Warszawa (2018)

6. K. Sałach, P. Lewandowski, Pomiar ubóstwa energetycznego na podstawie danych $B B G D$ - metodologia i zastosowanie (IBS research report, 2018)

7. Directive (EU) 2018/844 of the European Parliament and of the Council of 30 May 2018 amending Directive 2010/31/EU on the energy performance of buildings and Directive 2012/27/EU on energy efficiency (Text with EEA relevance) 